\title{
Influence of Marginal Maternal Zinc Deficiency on Pregnancy Outcome and Infant Zinc Status in Rhesus Monkeys
}

\author{
CARL L. KEEN, BO LÖNNERDAL, MARI S. GOLUB, JANET Y. URIU-HARE, \\ KATHERINE L. OLIN, ANDREW G. HENDRICKX, AND M. ERIC GERSHWIN \\ Departments of Nutrition and Internal Medicine and the California Primate Research Center, \\ University of California, Davis, California 95616
}

\begin{abstract}
To investigate the effects of marginal zinc deficiency on early development, rhesus monkeys were fed a diet marginally deficient in zinc $(\mathrm{M} ; 4 \mu \mathrm{g} / \mathrm{g})$ throughout pregnancy and during the first month of lactation. Despite the low concentration of zinc in the diet, $M$ dams did not develop overt signs of zinc deficiency. However, compared to control dams fed diets adequate in zinc $(C ; 100 \mu \mathrm{g} \mathrm{Zn} /$ g), $M$ dams showed a low response to the mitogens concanavalin $A$ and phytohemagglutinin. Pregnancy outcome was similar in the two groups and all of the neonates were judged to be healthy at delivery. From birth until d 30 of age, the infants were closely monitored for signs of zinc deficiency, and at $d \mathbf{3 0}$, they were killed and tissues were removed and analyzed for a number of parameters reported to be affected by zinc status. At birth, $M$ infants had low plasma zinc concentrations compared to controls; however, this difference was not observed at d 30. D $30 \mathrm{M}$ infants showed a normal response to the mitogens concanavalin $A$ and phytohemagglutinin, but showed a low response to pokeweed mitogen. Tissue (liver, brain, spleen, kidney, and heart) trace element concentrations were similar in the two groups of infants, as were liver metallothionein concentrations and ${ }^{65} \mathrm{Zn}$ uptake/retention by isolated hepatocytes. Infant wt gain was inversely correlated with plasma zinc, liver zinc, and liver metallothionein concentrations in both the $M$ and $C$ groups. These results demonstrate that feeding a diet containing $4 \mu \mathrm{g}$ zinc/g to rhesus monkeys during pregnancy and lactation does not result in marked signs of zinc deficiency, although subtle signs occur in both the mother and infant. The data also support the concept that infant growth is associated with a depletion of tissue zinc stores. (Pediatr Res 26:470-477, 1989)
\end{abstract}

\section{Abbreviations}

GGT, $\gamma$-glutamyl transferase

PHA, phytohemagglutinin

ConA, concanavalin A

PWM, pokeweed mitogen

MT, metallothionein

SOD, superoxide dismutase

KRB, Krebs Ringer buffer

FPLC, fast performance liquid chromatography

$M$, marginal zinc diet

$C$, control zinc diet

$\mathrm{CP}$, control zinc diet + placebo

Received April 18, 1989; accepted July 3, 1989.

Supported in part by HD14388, HD01743 and RR00169 from the National Institutes of Health.

Correspondence and reprint requests: Dr. Carl L. Keen, Department of Nutrition, University of California, Davis, CA 95616

\author{
MP, marginal zinc diet + placebo \\ RBC, red blood cells \\ Hct, hematocrit \\ $\mathrm{MCH}$, mean corpuscular $\mathrm{Hb}$ \\ MCHC, MCH concentration \\ MCV, mean corpuscular volume
}

The essentiality of adequate levels of dietary zinc during pregnancy and early development has been firmly demonstrated in laboratory rodents and domestic animals $(1,2)$. During the last several years there have been a number of studies that support the idea that maternal zinc status can be a predictor of pregnancy outcome in human populations $(1,3)$. However, in contrast to studies with experimental animal models in which the extent of the induced zinc deficiency is often severe, human populations are more likely to consume diets that are only marginally deficient in zinc. For this reason our group has initiated a long-term study on the effect of marginal zinc deficiency on pregnancy outcome and infant development in rhesus monkeys. To date, we have shown that marginal zinc deficiency during gestation and the early postnatal period can result in a syndrome characterized by growth retardation, delayed bone growth and mineralization, delayed puberty, decreased taste acuity, behavioral lethargy, and immune dysfunction (4-9).

Although the above studies have clearly demonstrated that the consumption of a diet marginal in zinc can have a profound effect on pregnancy outcome and infant development in a nonhuman primate, an understanding of the mechanisms underlying these developmental defects has been limited by the fact that the only maternal tissues that have been analyzed to date are blood and milk, whereas the only infant tissue that has been analyzed is blood. In an effort to better define the mechanisms underlying the effect of marginal zinc deprivation on development, in our study 30 -d-old rhesus infants born to mothers fed marginal zinc diets were killed and tissues were collected and analyzed for a number of variables reported to be affected by zinc deficiency. Results from these infants were compared to similar data collected from infants born to dams fed a diet adequate in zinc.

Inasmuch as it has been suggested that maternal iron supplementation during pregnancy may negatively affect maternal zinc status (10-13), we also evaluated the influence of moderate maternal iron supplementation on maternal and infant zinc status in both diet groups.

\section{MATERIALS AND METHODS}

Animals and Housing. Female rhesus monkeys (Macaca mulatta) 4-10 y of age were obtained from a breeding colony of 
healthy, multiparous monkeys maintained at the California Primate Research Center at the University of California, Davis, CA. Animals were housed individually in stainless steel cages in a temperature- $\left(70-85^{\circ} \mathrm{F}\right)$ and light-controlled room $(14: 10 ; \mathrm{L}: \mathrm{D})$ with 25-35 animals/room. Deionized distilled water was provided ad libitum via an automatic water system. Food was given in stainless steel containers to minimize both spillage of the purified diet and zinc contamination.

Diet and Breeding. Mating was accomplished by transferring the monkeys to a cage of a proven breeder for a 2 -h period on 2 alternate $\mathrm{d}$ around the estimated time of ovulation as determined from menstrual cycles. Mating was confirmed by vaginal swab for sperm immediately after the mating period. Pregnancy was determined at $25-35 \mathrm{~d}$ of gestation with RIA for monkey chorionic gonadotropin and/or ultrasound imaging examination. All animals determined to be nonpregnant were remated the next month. Experimental diets were initiated $2 \mathrm{wk}$ before the initial mating. Dams in the control group were fed a purified diet containing $100 \mu \mathrm{g} \mathrm{Zn/g}$, whereas dams in the marginal zinc group were fed the same diet, but with $4 \mu \mathrm{g} \mathrm{Zn} / \mathrm{g}$. The detailed composition of the diet is shown in Table 1 . To investigate the putative effect of maternal iron supplements on maternal and infant zinc status, half of the dams in each dietary group were given daily iron supplements of $4 \mathrm{mg}$ ferrous sulfate $/ \mathrm{kg}$ body wt. To ensure the consumption of the iron supplement, it was injected into a cookie which the monkeys found palatable. Nonsupplemented dams were given cookies injected with saline (placebo).

Diet Intake and Health Surveillance. Food intake was recorded during the last trimester of pregnancy because we have previously observed that marginal zinc deprivation can affect food intake during this time period (4). Stool consistency and general health were monitored daily. Dams were weighed on d 0, 45, 90, 135, and 150 of pregnancy, on the day of delivery, and on d 30 of lactation. Infants were weighed at birth and on postnatal d 10 and 30.

Experimental Procedures. Maternal. A total of 21 dams was successfully mated. The number of animals per group were as follows: control + placebo $(\mathrm{CP}), n=7$; control + iron supplement $(\mathrm{C}+\mathrm{Fe}), n=4$; marginal zinc + placebo $(\mathrm{MP}), n=5$; marginal zinc + iron supplement $(\mathrm{M}+\mathrm{Fe}), n=5$. At $\mathrm{d} 0,45,90,135$, and 150 of gestation, at delivery, and at $\mathrm{d} 10$ and 30 postpartum, blood samples were obtained from each of the dams for: $l$ ) complete blood counts; 2) serum calcium, phosphorus, creatinine, glucose, uric acid, protein, albumin, triglycerides, GGT,

Table 1. Diet composition

\begin{tabular}{lc}
\hline \multicolumn{1}{c}{ Ingredient } & Amount $(\mathrm{g} / \mathrm{kg}$ diet $)$ \\
\hline Spray-dried egg white & 250.0 \\
Cellulose & 70.0 \\
Sucrose & 554.72 \\
Corn oil & 80.00 \\
Choline bitartrate & 3.6 \\
Banana flavoring & 2.0 \\
Mineral mixture* & 37.56 \\
Vitamin mixture $\dagger$ & 2.12 \\
\hline
\end{tabular}

* Mineral mixture provided (g/kg diet): $\mathrm{CaCO}_{3}, 11.16 ; \mathrm{MgSO}_{4}, 2.40$; $\mathrm{CaHPO}_{4}, 6.31 ; \mathrm{K}_{2} \mathrm{HPO}_{4}, 12.96 ; \mathrm{FeSO}_{4} \cdot 7 \mathrm{H}_{2} \mathrm{O}, 0.89 ; \mathrm{NaCl}, 2.30 ; \mathrm{MnSO}_{4}$. $\mathrm{H}_{2} \mathrm{O}, 0.123 ; \mathrm{KI}, 0.0024 ; \mathrm{Na}_{2} \mathrm{SeO}_{3}, 0.00016 ; \mathrm{NaF}, 0.0009 ; \mathrm{CuCO}_{3}, 0.017$; $\mathrm{MgO}, 1.39 ; \mathrm{C}_{6} \mathrm{H}_{9} \mathrm{CrO}_{6}, 0.0018$.

† Vitamin mixture provided $(\mathrm{g} / \mathrm{kg}$ diet): taurine, 0.5 ; inositol, 0.005 ; ascorbic acid, 1.0; calcium pantothenate, 0.025 ; thiamin hydrochloride, 0.03 ; pyridoxine hydrochloride, 0.01 ; niacinamide, 0.25 ; menadione sodium bisulfite, 0.0802 ; riboflavin, 0.005 ; para-aminobenzoic acid, 0.01 ; folic acid, 0.005; biotin, 0.004; vitamin A palmitate, $0.03(500,000 \mathrm{U} /$ $\mathrm{g}$; vitamin $\mathrm{B}_{12}, 0.06(0.1 \%)$; vitamin $\mathrm{E}$ acetate, $0.1(500 \mathrm{U} / \mathrm{g})$; vitamin $\mathrm{D}_{3}, 0.005(400,000 \mathrm{U} / \mathrm{g})$. The above diet was adjusted to contain either 4 or $100 \mu \mathrm{g} \mathrm{Zn} / \mathrm{g}$ by the addition of $\mathrm{ZnCO}_{3}$. and alkaline phosphatase; 3) plasma zinc, copper, and iron; 4) plasma zinc distribution; 5) peripheral blood lymphocyte responsiveness to PHA, Con A, and PWM (see below). On d 100, amniocentesis was performed for amniotic fluid samples. Milk samples were collected on d 1-3, 10, and 30 of lactation. Milk was collected by gentle hand-stripping of the teats into plastic vials after the injection of the dams with oxytocin (2 IU). Amniotic fluid and milk were analyzed for zinc, copper, and iron concentrations.

Fasting blood samples were obtained between 1000 and 1130 $h$ from the cephalic vein of unanesthetized monkeys. Amniotic fluid samples were obtained from dams anesthetized with ketamine $(10 \mathrm{mg} / \mathrm{kg})$. Samples for the analysis of trace elements were drawn using plastic syringes. Blood samples were centrifuged at $1500 \times g$ for $10 \mathrm{~min}$ and the plasma was removed using plastic pipettes. Samples were frozen immediately after removal and stored at $-70^{\circ} \mathrm{C}$ in plastic vials.

Infants. Blood samples from the femoral vein were collected from the infants on postnatal d 10 and 30 . Infant blood samples were analyzed for the same parameters as those described for the dams. On postnatal d 30 the surviving infants were killed by an overdose of pentobarbital. Aliquots of liver, brain, kidney, thymus, and spleen were quickly removed, weighed, and frozen at $-70^{\circ} \mathrm{C}$ until analyzed for zinc, copper, iron, and manganese concentrations. Tissue copper concentrations were measured because they can be affected by cellular zinc status (14). Inasmuch as tissue manganese concentrations are not typically affected by dietary zinc intake, the measurement of this element allowed for a determination of specific versus general effects of the zinc deficiency on tissue mineral concentrations. One lobe of the liver was minced and incubated in a collagenase solution for isolation of hepatocytes. Hepatocyte ${ }^{65} \mathrm{Zn}$ uptake was assessed according to a modification of the method of Darwish et al. (15) as described below. Liver samples were also analyzed for MT concentration and the activity of the superoxide dismutases.

Immune Response. Immunologic assays of the animals were done using a mitogen test battery (PHA, Con A, PWM) for peripheral lymphocytes. Methods for these assays have been standardized previously and described in detail by our group (4). An optimal concentration of mitogen was used to elicit lymphocyte proliferation, and stimulation was expressed relative to background.

Mineral Analysis. Plasma ( $1 \mathrm{~mL})$, amniotic fluid (1 mL), milk $(1 \mathrm{~mL})$, and liver samples $(\sim 0.3 \mathrm{~g})$ were wet ashed with $16 \mathrm{~N}$ nitric acid ( $2 \mathrm{~mL}$ of Ultrex grade, J. T. Baker Co., SanFrancisco, CA), concentrated by evaporation and diluted with distilled deionized water as described by Clegg et al. (16). Trace element concentrations were determined in the diluted ashed samples by flame atomic absorption spectrophotometry (model IL 551, Instrumentation Laboratories, Wilmington, MA). Certified reference standards purchased from Fisher Scientific (Santa Clara, CA) were used to ensure reproducibility. Recovery of minerals from samples average $98-102 \%$ by these methods. A sample of NBS bovine liver (SRM 1577) purchased from the U.S. Department of Commerce, National Bureau of Standards, Washington, DC was included with the monkey tissue samples to ensure accuracy of the elemental analysis.

Plasma Zinc Distribution. The majority of zinc in plasma is associated with two pools; albumin, which represents a rapidly exchangeable zinc pool, and $\alpha$-2-macroglobulin, which represents a slowly exchangeable zinc pool. It is reasonable to suggest that a zinc deficiency-induced shift in the distribution of zinc between these pools could affect the transport of zinc into extrahepatic tissues. For this reason the distribution of zinc between these proteins was determined as described by Giroux (17).

$M T$. Hepatic MT concentration was analyzed by the cadmium saturation method of Onosaka and Cherian (18). Samples $(\sim 0.3$ g) were homogenized in $0.25 \mathrm{M}$ sucrose and centrifuged at 10 $000 \times g$. Supernatants were removed, and exposed to a $10 \mu \mathrm{g} /$ 
$\mathrm{mL}$ cadmium solution allowing maximum binding of cadmium to MT. Excess cadmium was removed by the addition of $\mathrm{Hb}$ and subsequent heat precipitation. Concentrations of MT were determined by analyzing for cadmium concentration and assuming a ratio of $6 \mathrm{~mol}$ of cadmium to $1 \mathrm{~mol}$ MT.

SOD Activity. Superoxide dismutase (SOD) activity was determined by inhibition of the autooxidation of pyrogallol as described by Marklund and Marklund (19). Samples of liver $(\sim 0.8$ g) were homogenized in cold $0.25 \mathrm{M}$ sucrose $(10 \%)$ and sonicated for 2 min (Insonator Model 500, Savant Instruments Inc., Hicksville, NY). The homogenates were centrifuged at $17000 \times g$ for $30 \mathrm{~min}$ at $4^{\circ} \mathrm{C}$ and the supernatants were removed for assay. Total SOD activity was determined in $50 \mathrm{mM}$ Tris-cacodylic acid, $1 \mathrm{mM}$ diethylenetriamine pentaacetic acid, $\mathrm{pH} 8.2$ at $25^{\circ} \mathrm{C}$. MnSOD activity was measured under the same conditions with the addition of $1 \mathrm{mM}$ potassium cyanide, which inhibits $\mathrm{Cu}$ ZnSOD.

Infant Hepatocyte ${ }^{65} \mathrm{Zn}$ Uptake. Two to $3 \mathrm{~g}$ of liver were minced and incubated in a modified KRB containing $1 \mathrm{mg} / \mathrm{mL}$ collagenase (Collagenase A, Mannheim Boehringer, Indianapolis, IN) for 40 to $50 \mathrm{~min}$ in a $37^{\circ} \mathrm{C}$ water bath. Isolated cells were filtered through a nitrex mesh $(105 \mu \mathrm{m})$. Cells were centrifuged at $750 \times g, 3 \mathrm{~min}$ at $4^{\circ} \mathrm{C}$ and washed with $\mathrm{KRB}$. The wash and centrifuge steps were repeated three more times. The cells were refiltered through mesh $(105 \mu \mathrm{m})$. Cell viability was assessed using the Trypan blue exclusion method. Cell preparations exceeded $95 \%$ viability. Suspensions of hepatocytes $\left(2 \times 10^{6}\right.$ cells/ $\mathrm{mL}$ ) were incubated in isolation medium in a shaking Dubonoff water bath for $10 \mathrm{~min}\left(100\right.$ oscillations $\left./ \mathrm{min}, 37^{\circ} \mathrm{C}\right)$, with flasks continually aerated with humidified $95 \% \mathrm{O}_{2}, 5 \% \mathrm{CO}_{2}$. At time zero, ${ }^{65} \mathrm{Zn}(0.7 \mu \mathrm{Ci} / \mathrm{mL})$ and cold zinc were added to give a final concentration of 5,10 , or $25 \mu \mathrm{M} \mathrm{Zn}$. The $1-\mathrm{mL}$ aliquots of cells were removed from incubation flasks at $5,10,15,30$, and $45 \mathrm{~s}$, and $1,1.5,2,4,5,10,15,30$, and $45 \mathrm{~min}$ after the addition of ${ }^{65} \mathrm{Zn}$. The aliquots were added to tubes containing $1 \mathrm{~mL}$ ice-cold $10 \mathrm{mM}$ EDTA in $0.9 \% \mathrm{NaCl}$ to minimize nonspecifically bound zinc. Tubes were centrifuged at $1500 \times \mathrm{g}, 4^{\circ} \mathrm{C}$ for $2 \mathrm{~min}$. The supernatant was aspirated off, $1 \mathrm{~mL}$ of ice-cold $0.9 \% \mathrm{NaCl}$ was added, and the cells were washed. Tubes were centrifuged at $1500 \times g, 2 \mathrm{~min}, 4^{\circ} \mathrm{C}$, supernatants aspirated off, and the cells were solubilized with $0.5 \mathrm{~mL}$ of $0.1 \%$ Triton $\mathrm{X}$. The tubes were counted in a Beckman $\gamma$-counter (Beckman Instruments, Fullerton, CA). Protein was determined using the bicinchoninic acid protein assay (Pierce Chemical Co., Rockford, IL) and results expressed as nmoles of $\mathrm{Zn} / \mathrm{mg}$ protein. For ${ }^{65} \mathrm{Zn}$ cell supernatant distribution analyses, flasks were incubated with ${ }^{65} \mathrm{Zn}(25 \mu \mathrm{M}$ $\mathrm{Zn}$ ) for $3 \mathrm{~h}$ and the total cells in each flask were washed with EDTA, centrifuged, and washed with $0.9 \% \mathrm{NaCl}$ as described above. Cells were then transferred to another tube with $1.5 \mathrm{~mL}$ of $0.25 \mathrm{M}$ sucrose, and sonicated. Homogenates were centrifuged at $17000 \times \mathrm{g}, 20 \mathrm{~min}, 4^{\circ} \mathrm{C}$. Pellets and supernatants were counted for radioactivity (Beckman $\gamma$-Counter). Supernatant fluids (200 $\mu \mathrm{L})$ were applied to a fast performance liquid chromatography column (Pharmacia Fine Chemicals, Piscataway, NJ) $(0.2 \mathrm{M}$ $\mathrm{NaCl}+10 \mathrm{mM}$ ammonium acetate buffer, $\mathrm{pH} 6.8$, flow rate 0.5 $\mathrm{mL} / \mathrm{min}$, fraction size $0.5 \mathrm{~mL}$ ). The protein absorption at 280 and $254 \mathrm{~nm}$, and radioactivity eluting from the column was determined.

Data analysis. All data were initially analyzed by multiple ANOVA using iron treatment and zinc treatment as variables. After the observation that iron supplementation had no effect on the outcome variables studied in either of the zinc groups, the \pm iron supplementation subgroups were collapsed within their respective dietary zinc groups. Similarly, sex was not found to be a significant factor for the infant variables examined; therefore, data for males and females were combined. After the combination of the subgroups; the data were reanalyzed using unpaired $t$ tests.

Assurance of Compliance with Animal Codes. All procedures conformed to the guidelines of the Animal Welfare Act and the
"Guide for the Care and Use of Laboratory Animals" of the National Research Council (20). The California Primate Research Center is fully accredited by AALAC. Individual protocols were approved by the campus veterinarian under the auspices of the Animal Care and Resources Committee of the University of California, Davis, CA.

\section{RESULTS}

Iron supplementation. Regardless of the dietary zinc intake, with a few exceptions iron supplementation was not found to affect the outcome variables reported in this paper. Iron supplementation did not affect either maternal or infant $\mathrm{Hb}$ concentrations. For example, maternal $\mathrm{Hb}$ concentrations on d 90 of gestation and d 30 of lactation were: CP $(11.3 \pm 0.4 ; 10.0 \pm 0.4$ $\mathrm{g} / \mathrm{dL}), \mathrm{C}+\mathrm{Fe}(11.1 \pm 0.4 ; 10.8 \pm 0.3 \mathrm{~g} / \mathrm{dL}), \mathrm{MP}(12.1 \pm 0.1 ;$ $10.7 \pm 0.1 \mathrm{~g} / \mathrm{dL})$, and $\mathrm{M}+\mathrm{Fe}(11.4 \pm 0.1 ; 10.7 \pm 0.5 \mathrm{~g} / \mathrm{dL})$. Infant $\mathrm{Hb}$ concentrations at birth and at $\mathrm{d} 30$ postnatal were $\mathrm{CP}$ $(16.5 \pm 0.6 ; 10.4 \pm 0.4 \mathrm{~g} / \mathrm{dL}), \mathrm{C}+\mathrm{Fe}(17.4 \pm 0.2 ; 10.4 \pm 1.12$ $\mathrm{g} / \mathrm{dL}), \mathrm{MP}(16.3 \pm 1.0 ; 9.4 \pm 1.2 \mathrm{~g} / \mathrm{dL})$, and $\mathrm{M}+\mathrm{Fe}(16.9 \pm$ $0.9 ; 10.6 \pm 0.5 \mathrm{~g} / \mathrm{dL})$. For this reason, data for the \pm iron supplement subgroups within each of the dietary zinc groups have been combined to facilitate data presentation and interpretation.

Maternal health and pregnancy outcome. Pronounced zinc deficiency was not recorded for any of the mothers at any point during the study, although cases of dermatitis were noted in both $\mathrm{C}$ and $\mathrm{M}$ dams. There were no significant differences in food intake between the $C$ and $M$ dams during the third trimester of pregnancy. Twenty-one percent (4/15) of the C and $28 \%(4 / 14)$ of the $\mathrm{M}$ dams failed to conceive despite three monthly matings. In the dams that did conceive, total pregnancy loss (abortion and stillbirth) was $18 \%(2 / 11)$ in the $C$ group and $20 \%(2 / 10)$ in the $M$ dams. The two abortions in the $C$ group occurred on $d 43$ and 44 of pregnancy and the two abortions in the $M$ group occurred on d 60 and 143. Gestation length was not influenced by diet.

No malformations were detected in the neonates. One infant in the $\mathrm{M}$ group had to be delivered by cesarean section when the pregnancy extended postterm and it was determined that a successful vaginal delivery was unlikely. This infant could not be reunited with the dam for nursing and it was killed at $\mathrm{d} 10$ postnatal to obtain tissues for experimental evaluation.

With regard to those dams that had a successful pregnancy, maternal wt gain during pregnancy was $153 \pm 16$ and $136 \pm 28$ $\mathrm{g}$ in $\mathrm{C}$ and $\mathrm{M}$ groups, respectively.

Maternal outcome. Maternal plasma zinc concentrations were similar in $\mathrm{C}$ and $\mathrm{M}$ dams at all time points tested; however, plasma zinc levels tended to be lower in $\mathrm{M}$ dams 1 wk before delivery, and on d 10 postdelivery (Table 2). Distribution of plasma zinc between serum albumin and $\alpha$-2-macroglobulin was not affected by diet (Table 2). Plasma copper and iron concentrations were similar between the groups at all time periods (Table 2). There were no consistent significant differences between $\mathrm{C}$ and $\mathrm{M}$ dams with respect to serum calcium, phosphorus, creatinine, glucose, alkaline phosphatase, total protein, albumin, globulin, GGT, uric acid, or triglyceride concentrations (unpublished data). Amniotic fluid zinc, copper, and iron concentrations at $\mathrm{d} 100$ were similar in the two groups $(\mathrm{Zn}, 0.087 \pm 0.008$, $0.155 \pm 0.087 ; \mathrm{Cu}, 0.075 \pm 0.007,0.080 \pm 0.006 ; \mathrm{Fe}, 0.075 \pm$ $0.013,0.075 \pm 0.021 \mu \mathrm{g} / \mathrm{mL}$ in $\mathrm{C}$ and $\mathrm{M}$ dams, respectively).

Peripheral lymphocyte response to mitogens varied widely among individuals; however, dams in the $M$ group showed a reduced responsiveness to PHA on d 45 and 90 , and to Con A on $\mathrm{d} 45,90$, and 135 of pregnancy and at term compared to controls (Table 3). Responsiveness to PWM was similar in the two groups.

Early milk ( $\mathrm{d} \mathrm{0-3)} \mathrm{zinc} \mathrm{concentrations} \mathrm{were} \mathrm{lower} \mathrm{in} \mathrm{M}$ dams than in $C$ dams $(2.83 \pm 0.60,5.23 \pm 1.18 \mu \mathrm{g} / \mathrm{mL}$, respectively); however, this difference was not statistically significant, due to the large variation among individuals. Day 0-3 milk copper and 
iron concentrations were similar for $\mathrm{C}$ and $\mathrm{M}$ dams $(\mathrm{Cu}, 3.91 \pm$ $0.61,3.07 \pm 0.26 ; \mathrm{Fe}, 0.37 \pm 0.03,0.58 \pm 0.26 \mu \mathrm{g} / \mathrm{mL}$ in $\mathrm{C}$ and $\mathrm{M}$ dams, respectively). At d 10 and 30 , milk zinc, copper, and iron concentrations were similar for $\mathrm{C}$ and $\mathrm{M}$ dams $(\mathrm{Zn}, \mathrm{d} 10$, $1.58 \pm 0.21,1.76 \pm 0.47$, d 30, $1.58 \pm 0.16,1.51 \pm 0.13 ; \mathrm{Cu}, \mathrm{d}$ $10,1.14 \pm 0.15,1.18 \pm 0.15$, d 30, 0.12 $\pm 0.06,0.17 \pm 0.04 ; \mathrm{Fe}$, $\mathrm{d} 10,0.17 \pm 0.05,0.46 \pm 0.25, \mathrm{~d} 30,0.30 \pm 0.03,0.38 \pm 0.04$ $\mu \mathrm{g} / \mathrm{mL}$ in $\mathrm{C}$ and $\mathrm{M}$ dams, respectively).

Infant outcome. Body wt at birth and d 30 were similar for $\mathrm{C}$ and $M$ infants (Table 4). However, infant birth weight as a percent of maternal wt on d 0 of gestation tended to be lower in the $\mathrm{M}$ group than in controls ( $p \leq 0.052$ ). Liver, kidney, brain,

Table 2. Influence of marginal zinc diet on maternal plasma zinc, copper, and iron concentrations*

\begin{tabular}{|c|c|c|c|c|c|c|c|}
\hline $\mathrm{D}$ & Group & $(n)$ & $\begin{array}{c}\text { Zinc } \\
(\mu \mathrm{g} / \mathrm{mL})\end{array}$ & $\%$ albumin & $\begin{array}{c}\% \\
\alpha \text {-2-macroglobulin }\end{array}$ & $\begin{array}{l}\text { Copper } \\
(\mu \mathrm{g} / \mathrm{mL})\end{array}$ & $\begin{array}{c}\text { Iron } \\
(\mu \mathrm{g} / \mathrm{mL})\end{array}$ \\
\hline \multicolumn{8}{|l|}{ Gestation } \\
\hline \multirow[t]{2}{*}{0} & $\mathrm{C}$ & (6) & $0.66 \pm 0.05$ & $46.68 \pm 5.49$ & $53.32 \pm 5.49$ & $1.07 \pm 0.10$ & $1.04 \pm 0.27$ \\
\hline & M & (2) & $0.84 \pm 0.18$ & $55.56 \pm 15.94$ & $44.44 \pm 15.94$ & $1.12 \pm 0.09$ & $1.51 \pm 0.07$ \\
\hline \multirow[t]{2}{*}{45} & $\mathrm{C}$ & (9) & $0.81 \pm 0.03$ & $55.90 \pm 2.61$ & $44.10 \pm 2.61$ & $1.30 \pm 0.06$ & $1.19 \pm 0.17$ \\
\hline & $\mathrm{M}$ & (7) & $0.96 \pm 0.13$ & $60.14 \pm 6.17$ & $39.86 \pm 6.17$ & $1.02 \pm 0.09 \dagger$ & 2.17 \\
\hline \multirow[t]{2}{*}{90} & $\mathrm{C}$ & (9) & $0.95 \pm 0.08$ & $64.51 \pm 5.39$ & $37.10 \pm 4.94$ & $1.49 \pm 0.09$ & $1.09 \pm 0.13$ \\
\hline & M & (7) & $0.83 \pm 0.10$ & $47.70 \pm 3.20 \dagger$ & $52.30 \pm 3.20 \dagger$ & $1.30 \pm 0.12$ & $1.78 \pm 0.25$ \\
\hline \multirow[t]{2}{*}{135} & $\mathrm{C}$ & (9) & $0.78 \pm 0.05$ & $62.15 \pm 6.72$ & $37.85 \pm 6.72$ & $1.64 \pm 0.11$ & $1.23 \pm 0.12$ \\
\hline & M & (7) & $0.77 \pm 0.09$ & $57.53 \pm 6.69$ & $42.47 \pm 6.69$ & $1.51 \pm 0.07$ & $1.56 \pm 0.11$ \\
\hline \multirow[t]{2}{*}{150} & $\mathrm{C}$ & (7) & $0.80 \pm 0.05$ & $60.60 \pm 11.50$ & $39.40 \pm 11.50$ & $1.98 \pm 0.15$ & $1.36 \pm 0.34$ \\
\hline & $\mathrm{M}$ & (4) & $0.69 \pm 0.05$ & $81.98 \pm 5.44$ & $18.03 \pm 5.44$ & $1.91 \pm 0.09$ & $1.49 \pm 0.28$ \\
\hline \multirow{2}{*}{ Delivery } & $\mathrm{C}$ & (9) & $0.67 \pm 0.05$ & $66.72 \pm 9.27$ & $33.28 \pm 9.27$ & $2.20 \pm 0.11$ & $1.34 \pm 0.07$ \\
\hline & $\mathrm{M}$ & (7) & $0.75 \pm 0.06$ & $62.52 \pm 7.85$ & $37.48 \pm 7.85$ & $1.93 \pm 0.19$ & $1.21 \pm 0.13$ \\
\hline \multicolumn{8}{|l|}{ Lactation } \\
\hline \multicolumn{8}{|l|}{ Day } \\
\hline \multirow[t]{2}{*}{10} & $\mathrm{C}$ & (8) & $0.98 \pm 0.06$ & $73.57 \pm 2.34$ & $26.93 \pm 2.65$ & $0.94 \pm 0.08$ & $1.34 \pm 0.13$ \\
\hline & M & (7) & $0.78 \pm 0.08$ & $68.57 \pm 5.12$ & $31.43 \pm 5.12$ & $0.82 \pm 0.16$ & $1.44 \pm 0.20$ \\
\hline \multirow[t]{2}{*}{30} & $\mathrm{C}$ & (8) & $0.83 \pm 0.06$ & $60.82 \pm 10.09$ & $39.18 \pm 10.09$ & $0.74 \pm 0.07$ & $0.93 \pm 0.13$ \\
\hline & $M$ & (7) & $0.71 \pm 0.04$ & $64.28 \pm 1.49$ & $35.72 \pm 1.49$ & $0.61 \pm 0.07$ & $1.20 \pm 0.09$ \\
\hline
\end{tabular}

${ }^{*} \mathrm{C}=$ control zinc $\operatorname{diet}(100 \mu \mathrm{g} \mathrm{Zn/g}) ; \mathrm{M}=$ marginal zinc diet $(4 \mu \mathrm{g} \mathrm{Zn} / \mathrm{g}$ diet $) .(n)=$ number of animals. Data are shown as mean $\pm \mathrm{SE}$.

$\dagger$ Significantly different from control values $(p<0.05)$.

Table 3. Influence of marginal zinc diet on peripheral blood lymphocyte response to the mitogens Con $A$, PHA, and PWM in dams and $d 30$ infants*

\begin{tabular}{|c|c|c|c|c|c|}
\hline $\mathrm{D}$ & Group & $(n)$ & Con A & PHA & PWM \\
\hline \multicolumn{6}{|l|}{ Dams } \\
\hline \multirow[t]{2}{*}{0} & C & $(9)$ & $38.6 \pm 4.73$ & $48.7 \pm 5.1$ & $7.5 \pm 1.0$ \\
\hline & M & (7) & $36.9 \pm 6.24$ & $38.7 \pm 3.3$ & $9.3 \pm 1.5$ \\
\hline \multirow[t]{2}{*}{45} & $\mathrm{C}$ & $(9)$ & $46.3 \pm 3.12$ & $62.5 \pm 8.0$ & $12.5 \pm 1.5$ \\
\hline & M & (7) & $14.2 \pm 2.65 \dagger$ & $20.5 \pm 5.2 \dagger$ & $9.8 \pm 2.7$ \\
\hline \multirow[t]{2}{*}{90} & $\mathrm{C}$ & (9) & $79.5 \pm 4.77$ & $92.5 \pm 10.3$ & $22.8 \pm 2.4$ \\
\hline & M & (7) & $43.5 \pm 2.85 \dagger$ & $48.8 \pm 4.1 \dagger$ & $18.0 \pm 2.1$ \\
\hline \multirow[t]{2}{*}{135} & $\mathrm{C}$ & $(9)$ & $41.0 \pm 3.68$ & $35.0 \pm 3.2$ & $10.6 \pm 2.0$ \\
\hline & M & (7) & $15.6 \pm 2.36 \dagger$ & $43.8 \pm 3.6$ & $10.3 \pm 2.8$ \\
\hline \multirow[t]{2}{*}{ Term } & $\mathrm{C}$ & (9) & $38.4 \pm 8.10$ & $43.6 \pm 4.6$ & $11.0 \pm 2.3$ \\
\hline & M & (7) & $15.2 \pm 2.39 \dagger$ & $36.0 \pm 6.4$ & $7.8 \pm 0.9$ \\
\hline \multirow[t]{2}{*}{ D 30 postpartum } & $\mathrm{C}$ & (9) & $28.9 \pm 3.86$ & $47.6 \pm 6.7$ & $9.6 \pm 1.3$ \\
\hline & M & (7) & $30.9 \pm 5.57$ & $40.1 \pm 9.1$ & $9.0 \pm 2.3$ \\
\hline \multicolumn{6}{|l|}{ Infant } \\
\hline \multirow[t]{2}{*}{ D 30} & $\mathrm{C}$ & (9) & $51.0 \pm 8.0$ & $47.4 \pm 6.9$ & $24.1 \pm 6.2$ \\
\hline & $\mathrm{M}$ & $(7)$ & $41.6 \pm 13.1$ & $52.6 \pm 13.7$ & $14.8 \pm 5.3$ \\
\hline
\end{tabular}

${ }^{*} \mathrm{C}=$ control zinc diet $(100 \mu \mathrm{g} \mathrm{Zn/g}) ; \mathrm{M}=$ marginal zinc diet $(4 \mu \mathrm{g} \mathrm{Zn} / \mathrm{g}$ diet $)$. Data are shown as the mean stimulation index. $(n)=$ number of animals. Data are shown as mean $\pm \mathrm{SE}$.

$\dagger$ Significantly different from control values $(p<0.05)$. 
spleen, and thymus at d 30 were similar between the groups, whereas adrenal weights were higher in the $M$ infants than in controls.

At birth, plasma zinc concentrations in $\mathrm{M}$ infants were significantly lower than in C infants (Table 5). Plasma zinc levels were also lower in $\mathrm{M}$ infants than in controls on $\mathrm{d} 10$ and 30; however, these differences were not statistically significant. Plasma copper and iron concentrations were similar in the two groups. There

Table 4. Influence of maternal marginal zinc intake on infant wt and growth and tissue size on postnatal $d 30^{*}$

\begin{tabular}{ccc}
\hline & $\mathrm{C}$ & $\mathrm{M}$ \\
\hline Birth wt $(\mathrm{g})$ & $482 \pm 22$ & $443 \pm 21$ \\
\% Maternal wt $\dagger$ & $9.31 \pm 0.43$ & $8.05 \pm 0.38$ \\
& & \\
D 30 wt $(\mathrm{g})$ & $603 \pm 36$ & $579 \pm 40$ \\
Wt gain (g) & $122 \pm 24$ & $137 \pm 30$ \\
Liver (g) & $17.83 \pm 1.96$ & $16.21 \pm 0.87$ \\
\% body wt & $2.81 \pm 0.17$ & $2.85 \pm 0.16$ \\
& & \\
Kidney (g) & $3.29 \pm 0.22$ & $3.31 \pm 0.34$ \\
\% body wt & $0.55 \pm 0.02$ & $0.57 \pm 0.04$ \\
& & \\
Thymus (g) & $2.60 \pm 0.25$ & $2.81 \pm 0.57$ \\
\% body wt & $0.43 \pm 0.04$ & $0.45 \pm 0.08$ \\
Spleen (g) & $1.04 \pm 0.10$ & $1.11 \pm 0.13$ \\
\% body wt & $0.17 \pm 0.01$ & $0.19 \pm 0.01$ \\
& & \\
Adrenal (g) & $0.37 \pm 0.03$ & $0.45 \pm 0.06 \ddagger$ \\
\% body wt & $0.061 \pm 0.002$ & $0.077 \pm 0.007$ \\
\hline
\end{tabular}

${ }^{*} \mathrm{C}=$ control zinc $\operatorname{diet}(100 \mu \mathrm{g} \mathrm{Zn/g})(n=9) ; \mathrm{M}=$ marginal zinc diet $(4 \mu \mathrm{g} \mathrm{Zn/g} \mathrm{diet)}(n=7)$. Data are shown as mean $\pm \mathrm{SE}$.

$\dagger$ Expressed as a percent of maternal body wt on day 0 of gestation.

$\ddagger$ Significantly different at $p<0.05$.

Table 5. Influence of maternal marginal zinc intake on infant plasma zinc, copper, and iron concentrations*

\begin{tabular}{cccccc}
\hline $\mathrm{D}$ & Group & $(n)$ & Zinc & Copper & Iron \\
\hline 0 & $\mathrm{C}$ & $(7)$ & $0.90 \pm 0.07 \dagger$ & $0.72 \pm 0.10$ & $2.31 \pm 0.39$ \\
& $\mathrm{M}$ & $(7)$ & $0.66 \pm 0.06$ & $0.57 \pm 0.09$ & $2.81 \pm 1.10$ \\
& & & & & \\
10 & $\mathrm{C}$ & $(8)$ & $0.97 \pm 0.10$ & $0.90 \pm 0.12$ & $2.77 \pm 0.60$ \\
& $\mathrm{M}$ & $(7)$ & $0.71 \pm 0.08$ & $0.87 \pm 0.14$ & $1.53 \pm 0.48$ \\
30 & $\mathrm{C}$ & $(6)$ & $0.80 \pm 0.06$ & $0.84 \pm 0.05$ & $1.46 \pm 0.20$ \\
& $\mathrm{M}$ & $(5)$ & $0.73 \pm 0.05$ & $0.95 \pm 0.21$ & $1.19 \pm 0.17$ \\
\hline
\end{tabular}

${ }^{*} \mathrm{C}=$ control zinc $\operatorname{diet}(100 \mu \mathrm{g} \mathrm{Zn} / \mathrm{g}) ; \mathrm{M}=$ marginal zinc diet $(4 \mu \mathrm{g}$ $\mathrm{Zn} / \mathrm{g}$ diet). $(n)=$ number of animals. Data are shown as $\mu \mathrm{g} / \mathrm{mL}$; mean $\pm \mathrm{SE}$.

$\dagger$ Significantly different at $p<0.05$. were no significant differences in liver, kidney, or brain zinc, copper, iron, or manganese concentrations between the two groups (Table 6). Mean liver MT concentrations were $142 \pm 46$ and $135 \pm 55 \mu \mathrm{g} / \mathrm{g}$ in $\mathrm{C}$ and $\mathrm{M}$ infants, respectively. Hepatic $\mathrm{CuZnSOD}$ and MnSOD activities were similar in the two groups (CuZnSOD, $1327 \pm 99,1164 \pm 99$; MnSOD, $353 \pm 26,316 \pm$ $58 \mathrm{U} / \mathrm{g}$ tissue in $\mathrm{C}$ and $\mathrm{M}$ infants, respectively) and values were similar to those previously reported for Macaca mulatta (21).

Zinc- 65 uptake/retention by isolated hepatocytes was not different between $C$ and $M$ infants when incubated in physiological concentrations of 5,10 , or $25 \mu \mathrm{M}$ zinc solutions. Pooled data from all infants initially show a rapid first phase of ${ }^{65} \mathrm{Zn}$ association with cells and a slow, second phase ${ }^{65} \mathrm{Zn}$ accumulation over time (Fig. 1). The subcellular cytosolic distribution of zinc from cells incubated for $3 \mathrm{~h}$ shows that $99 \%$ of the ${ }^{65} \mathrm{Zn}$ was associated with a single peak which eluted after the purified rat Cd-MT peak, at a similar time as the glutathione-bound $\mathrm{Zn}$ peak and before the free zinc peak (Fig. 2).

Because of previous reports suggesting the possibility of subclinical anemia in $\mathrm{M}$ dams and their offspring (4-6), a detailed analysis of infant hematologic parameters was conducted. In contrast to previous findings, there were no group differences in $\mathrm{RBC}$ number, $\mathrm{Hb}$ concentration, $\mathrm{Hct}, \mathrm{MCH}$, and $\mathrm{MCHC}$, or MCV (Table 7). Concentrations of serum calcium, phosphorus, creatinine, glucose, uric acid, protein, albumin, globulin, GGT, and alkaline phosphatase were similar among groups (Keen CL, et al., unpublished data). Serum triglyceride concentrations tended to be lower in $\mathrm{M}$ infants than in C infants (55 \pm 11 versus $96 \pm 17 \mathrm{mg} / \mathrm{dL}, \mathrm{p}<0.08)$. Similar to the dams, there was considerable variation among infants in mitogen responsiveness;

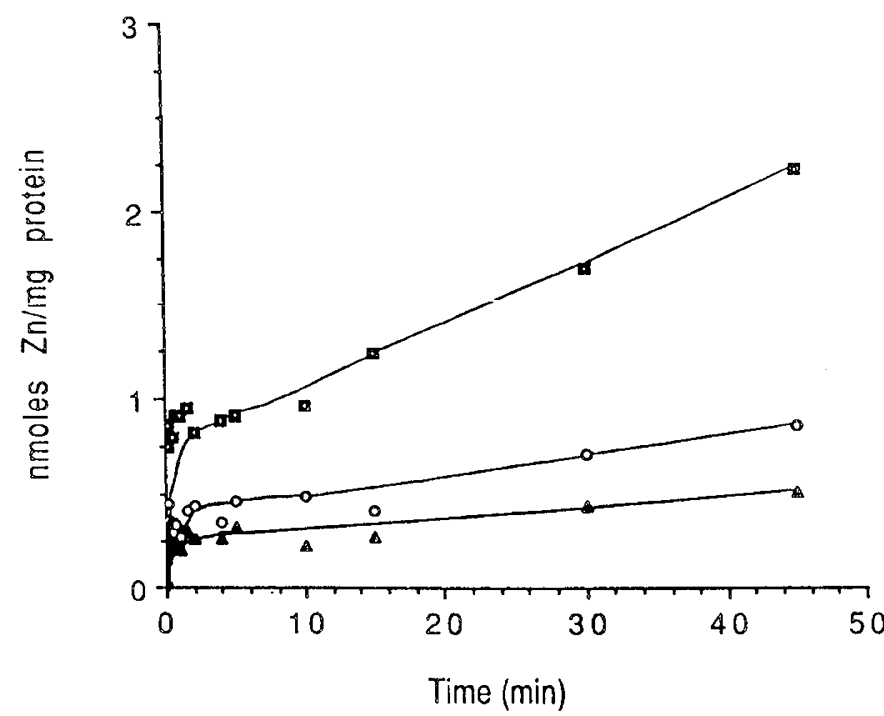

Fig. 1. Uptake of ${ }^{65} \mathrm{Zn}[5(\mathbf{\Lambda}), 10(\mathrm{O}), 25(\square) \mu \mathrm{M} \mathrm{Zn}]$ by isolated infant monkey hepatocytes. Each point represents the mean of 7-14 separate hepatocyte preparations done in duplicate.

Table 6. Influence of maternal marginal zinc intake on liver, brain, and kidney zinc, copper, iron, and manganese concentrations $(\mu \mathrm{g} / \mathrm{g})$ in d 30 infants*

\begin{tabular}{ccccccc}
\hline Tissue & Group & $(n)$ & Zinc & Copper & Iron & Manganese \\
\hline Liver & C & $(9)$ & $25.96 \pm 2.16$ & $20.30 \pm 3.84$ & $296 \pm 32$ & $0.76 \pm 0.12$ \\
& M & $(7)$ & $23.32 \pm 2.15$ & $16.19 \pm 3.02$ & $213 \pm 46$ & $0.75 \pm 0.11$ \\
Brain & C & $(9)$ & $9.60 \pm 0.29$ & $1.62 \pm 0.10$ & $7.57 \pm 0.47$ & $0.18 \pm 0.03$ \\
& M & $(7)$ & $9.46 \pm 0.39$ & $1.46 \pm 0.06$ & $7.43 \pm 0.34$ & $0.21 \pm 0.02$ \\
Kidney & & & & & & \\
& C & $(9)$ & $17.64 \pm 0.43$ & $2.61 \pm 0.10$ & $29.85 \pm 4.35$ & $0.70 \pm 0.25$ \\
& M & $(7)$ & $17.21 \pm 0.71$ & $2.60 \pm 0.20$ & $30.02 \pm 3.57$ & $0.46 \pm 0.06$ \\
\hline
\end{tabular}

${ }^{*} \mathrm{C}=$ control zinc diet $(100 \mu \mathrm{g} \mathrm{Zn/g)}(n=9) ; \mathrm{M}=$ marginal zinc diet $(4 \mu \mathrm{g} \mathrm{Zn} / \mathrm{g}$ diet $)(n=7)$. Data are shown as mean $\pm \mathrm{SE}$. 
however, $\mathrm{M}$ infants tended to have a lower response to PWM than did $\mathrm{C}$ infants $(p \leq 0.22)$ (Table 3 ).

Regression analysis. To further investigate the influence of infant zinc status on infant growth and development, data from the $C$ and $M$ infants were pooled for regression analysis. Significant correlations were observed between liver zinc concentrations and liver MT levels $(r=0.71 ; p \leq 0.01$; Fig. 3 top $)$, and infant wt gain $(r=-0.65 ; p \leq 0.01$; Fig. 3 bottom $)$. Similar to liver zinc, plasma zinc concentration at d 30 was significantly correlated with infant wt gain $(r=-0.67 ; p=0.01$; Fig. 4). Regression analysis did not reveal any significant associations between growth and tissue copper, iron, or manganese levels.

\section{DISCUSSION}

Consistent with our previous reports (4-9), the results obtained in the current study support the idea that a semipurified diet containing $4 \mu \mathrm{g} \mathrm{Zn/g}$ represents a "marginal" zinc diet for the pregnant/lactating rhesus monkey. Similar to previous findings (4-6), neither maternal nor infant plasma zinc levels were mark(edly affected by the level of zinc deprivation used in this study, even though there was an effect of zinc intake on the responsiveness of the immune system in both the mothers and infants. The above observation reinforces the idea that plasma zinc can at times be a poor indicator of zinc status $(22,23)$, and supports the concept that in some situations a more sensitive index of zinc status may be a subject's response to mitogen challenges (6, 24-27). Given the observation in our study that maternal and infant immune responsiveness was impaired in the absence of many of the classical signs of zinc deficiency, this suggests that $T$ cell function is particularly sensitive to either modest changes in cellular zinc concentrations and/or is responsive to early zinc deficiency-induced alterations in cellular metabolism. These observations underscore the risk of "marginal" maternal zinc defi-

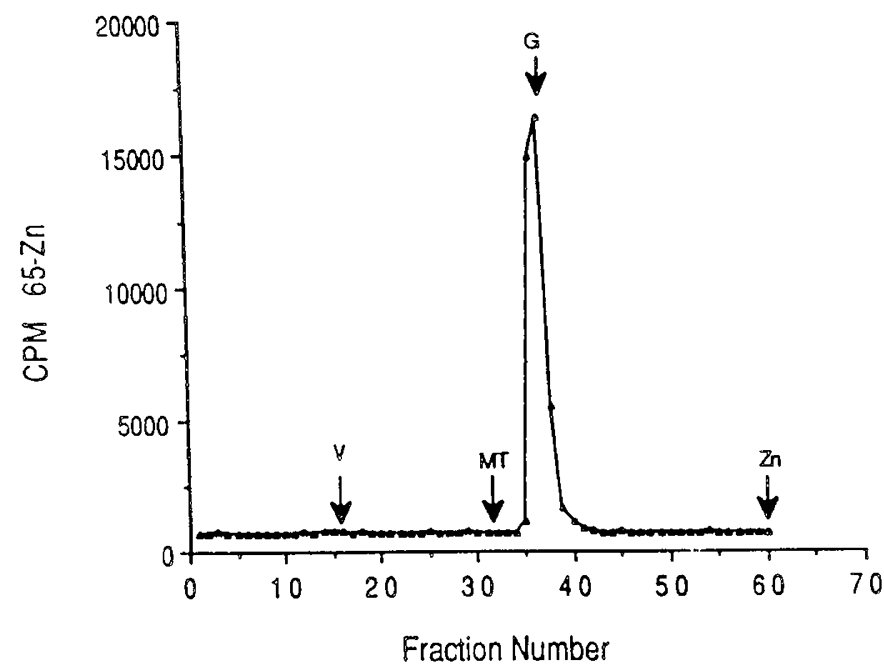

Fig. 2. FPLC on Superose 12 of infant monkey hepatocyte cell cytosol after $3 \mathrm{~h}$ incubation in $25 \mu \mathrm{M} \mathrm{Zn}$ and $1.4 \mu \mathrm{Ci}{ }^{65} \mathrm{Zn}$. V, MT, G, and $\mathrm{Zn}$ designate elution fractions of blue dextran, purified rat liver cadmiummetallothionein $n_{I I}$, glutathione-bound $\mathrm{Zn}$, and free ${ }^{65} \mathrm{Zn}$, respectively. ciency because reduced immunocompetence may result in increased susceptibility to infection that in turn can lead to complications during pregnancy and lactation. Although all of the mothers and infants in our study were judged to be healthy throughout the experimental period based on cage surveillance, it is important to recognize that these animals were protected from excess exposure to infections. Mukherjee et al. (28) have reported an association between low first trimester maternal plasma zinc concentrations in humans and the incidence of amnionitis and endometritis.

Consistent with our previous findings, the marginal zinc diet had little influence on maternal serum chemistry $(4,29)$. Our laboratory has reported the occurrence of a subclinical anemia in $\mathrm{M}$ dams and infants $(4,5)$ which was expressed in about onethird of the pregnant dams and infants; the anemia was typically characterized by a low packed cell volume, low $\mathrm{Hb}$ concentration and a low MCV. In contrast to the previous findings using the above criteria, none of the animals in our study was anemic. Two possible explanations for the difference between the present study and the previous ones in which an anemia was observed are that 1 ) the extent of the zinc deficiency induced in the $\mathrm{M}$ animals in previous studies was more severe due to differences

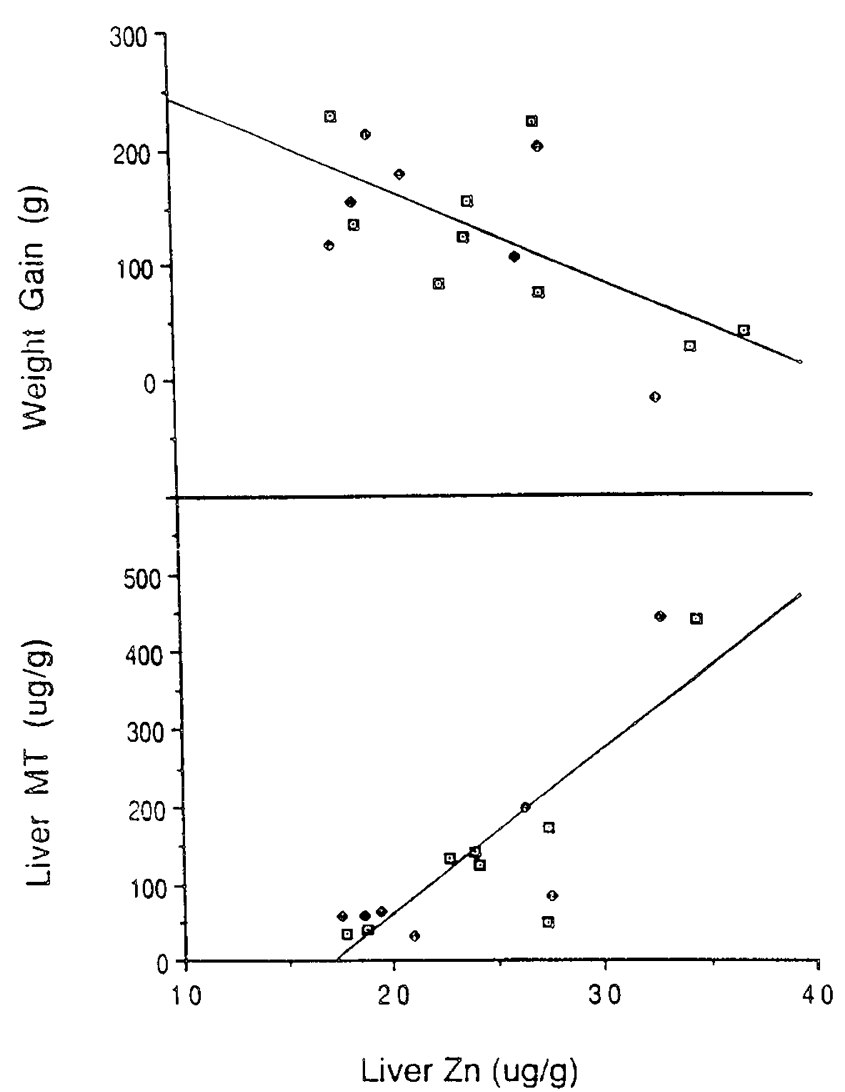

Fig. 3. Relationship between liver zinc concentration and liver metallothionein concentration $(2 \mathrm{a} ; r=0.71)$ and liver zinc concentration and infant wt gain $(2 \mathrm{~b} ; r=-0.65)$. Control infants $=\square$; marginal zinc infants $=\bullet$.

Table 7. Influence of maternal marginal zinc intake on hematologic values in newborn and $d 30$ infants*

\begin{tabular}{|c|c|c|c|c|c|c|c|c|}
\hline $\mathrm{D}$ & Group & $(n)$ & $\begin{array}{c}\mathrm{RBC} \\
\left(\times 10^{6} / \mathrm{mm}^{3}\right)\end{array}$ & $\begin{array}{c}\mathrm{Hb} \\
(\mathrm{g} / 100 \mathrm{~mL})\end{array}$ & Het $(\%)$ & $\operatorname{MCV}\left(\mu \mathrm{m}^{3}\right)$ & $\mathrm{MCHC}(\%)$ & $\mathrm{MCH}(\mathrm{pg})$ \\
\hline \multirow[t]{2}{*}{0} & $\bar{C}$ & (9) & $5.46 \pm 0.15$ & $16.92 \pm 0.38$ & $49.73 \pm 1.26$ & $91.22 \pm 0.93$ & $33.20 \pm 0.53$ & $31.94 \pm 0.59$ \\
\hline & M & (7) & $5.29 \pm 0.16$ & $16.61 \pm 0.63$ & $48.80 \pm 1.45$ & $92.43 \pm 1.70$ & $34.13 \pm 0.74$ & $31.36 \pm 0.94$ \\
\hline \multirow[t]{2}{*}{30} & $\mathrm{C}$ & $(8)$ & $3.93 \pm 0.22$ & $10.45 \pm 0.45$ & $30.70 \pm 1.57$ & $78.50 \pm 0.96$ & $34.04 \pm 0.32$ & $26.69 \pm 0.48$ \\
\hline & M & (7) & $3.89 \pm 0.22$ & $10.06 \pm 0.57$ & $30.36 \pm 1.61$ & $78.29 \pm 1.52$ & $33.09 \pm 0.43$ & $25.87 \pm 0.64$ \\
\hline
\end{tabular}

\footnotetext{
$* \mathrm{C}=$ control zinc diet $(100 \mu \mathrm{g} \mathrm{Zn/g}) ; \mathrm{M}=$ marginal zinc diet $(4 \mu \mathrm{g} \mathrm{Zn} / \mathrm{g}$ diet $) .(n)=$ number of animals. Data are shown as mean $\pm \mathrm{SE}$.
} 


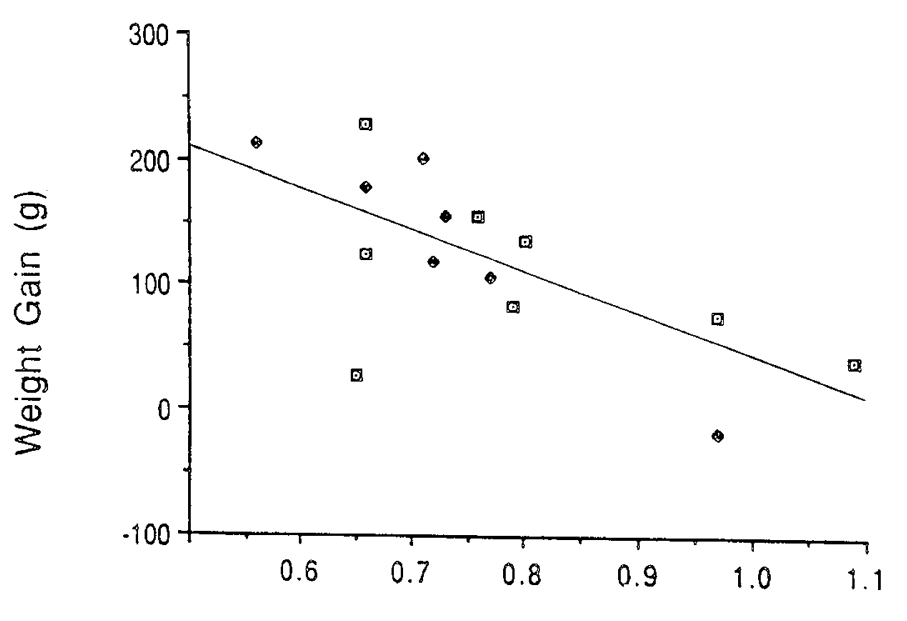

Plasma Zn (ug/ml)

Fig. 4. Relationship between plasma zinc concentrations and infant wt gain $(r=-0.67)$. Control infants $=\odot$; marginal zinc infants $=\bullet$.

in genetic background, or 2) the previously observed anemia had multiple origins. With regard to the first possibility, it is important to note that there has been a very heterogeneous response to the marginal zinc diets in the previous studies. For example, in addition to the subgroup of $\mathrm{M}$ dams which developed anemia in the previous work, anorexia, reduced wt gain, and dermatitis occurred in subgroups of $\mathrm{M}$ dams (4). Taken together, the large variability in maternal response to $M$ diets underscores the need to recognize that a similar degree of variability probably occurs in the human population. With regard to the possibility that the previously recognized anemia may have had multiple origins, it is important to stress the fact that the level of copper in the current diet was increased from 2 to $7 \mu \mathrm{g} / \mathrm{g}$, based on our previous observation of low plasma copper concentrations in dams fed $\mathrm{M}$ or C diets for long periods of time (29), and the finding of low plasma copper levels in the neonates of $\mathrm{C}$ and $\mathrm{M}$ dams (5). Maternal and infant plasma copper levels were markedly higher in the current study compared to the previous work $(5,29)$, supporting the idea that dietary copper may have been marginal in the previous studies and that the previously recognized anemia may have been due to a combination of marginal zinc and copper deficiency.

In contrast to our previous findings $(4,5,8)$, we did not observe a strong effect of zinc deprivation on maternal wt gain, infant birth wt, or early infant growth. However, initial maternal body wt was higher in the $M$ group than in the $C$ group, and when infant birth wt was examined relative to maternal wt, it was observed that $M$ infants were lighter than $C$ infants, suggesting that the low zinc diets may have affected the genetic potential for growth in these infants. Consistent with the idea that zinc can be an important regulator of perinatal growth is our observation that both infant plasma zinc and liver zinc concentrations at d 30 were inversely correlated to infant wt gain, suggesting that zinc stores may be used during rapid growth. We suggest that the observation of a strong inverse correlation between liver MT levels and growth rate is further evidence for the above idea. Although many functions for MT have been proposed, several lines of evidence support the idea that one function of MT during early life may be that of a zinc-storage protein $(30,31)$. Supportive of this idea is the finding of similar negative correlations between maternal plasma zinc at term and birth wt in human populations (32-34).

Similar to the dams, the serum chemistry and hematology of the $M$ infants was not markedly different from controls. $M$ infants had significantly lower plasma zinc concentrations at birth than did controls; however, this difference was no longer evident by $\mathrm{d} 30$. It is interesting to note that although milk zinc concentrations were lower in the $\mathrm{M}$ group than in controls during early lactation, this difference was no longer evident at d 30; thus, by this time the dietary zinc intake of $M$ infants was similar to that of $\mathrm{C}$ infants despite differences in their mothers' dietary zinc intake.

One of the objectives of our study was to initiate investigations on the influence of marginal zinc deficiency on hepatic trace mineral concentrations and metabolism in the 30-d-old infant. We have previously reported that when adult rhesus monkeys are fed a marginal zinc diet for $15 \mathrm{mo}$, they are characterized by low concentrations of hepatic zinc and MT, and high levels of hepatic iron compared to controls (21). In our study, however, there was no significant difference between $C$ and $M$ infants with respect to the above hepatic measurements. Our observation of an effect of the $M$ diet in the adult animal, but not in the infant, is surprising because we had predicted that the rapidly growing infant would be more sensitive to the deficiency than the mature adult. One explanation for our observation is that the $M$ infant may have been able to partially compensate for its "deficiency" by increasing its retention of dietary zinc and/or by reducing its endogenous loss of the metal. Although this is an attractive idea, the lack of differences between $C$ and $M$ infants with regard to hepatic uptake of ${ }^{65} \mathrm{Zn}$, would seem to argue against this hypothesis. However, we have observed that the retention of ${ }^{65} \mathrm{Zn}$ from ${ }^{65} \mathrm{Zn}$-labeled meals given to both the mother and infant is slightly higher in the $M$ group than in the $C$ group. Thus, there is evidence that the $M$ diet may result in changes in whole body zinc (35). A second explanation is that by d 30 postnatally, the major impact of the $M$ diets with regard to tissue zinc concentrations may have subsided; i.e. to have detected a difference in tissue zinc levels it may have been necessary to take a biopsy sample from the infants at birth. A third possible explanation is that in the rapidly growing infant, cellular zinc concentrations act to modulate the rate of cell hyperplasia and hypertrophy; thus, once any cellular zinc "stores" are exhausted the result would be an impairment in the growth potential of the tissue rather than in cellular zinc concentrations. In contrast to the infant, in the mature adult tissue, growth would be minimal, thus potentially making differences in the cellular flux of zinc in $\mathrm{M}$ and $\mathrm{C}$ animals easier to detect.

Experiments conducted to investigate the effect of marginal zinc deficiency on infant hepatic ${ }^{65} \mathrm{Zn}$ metabolism showed that there were no differences in hepatic ${ }^{65} \mathrm{Zn}$ uptake/retention between $\mathrm{M}$ and $\mathrm{C}$ infants. Recently, House et al. (36) reported that the ${ }^{65} \mathrm{Zn}$ hepatic uptake from zinc-deficient and zinc-adequate rats were similar when incubated in $25 \mu \mathrm{M} \mathrm{Zn}$ solutions, but the hepatocytes from zinc-deficient rats took up less zinc when incubated in 100,250 , and $500 \mu \mathrm{M}$ solutions compared to control hepatocytes. In this study, zinc solutions of 100 and 250 $\mu \mathrm{M} \mathrm{Zn}$ were cytotoxic to monkey hepatocytes from either diet group. The kinetics of hepatic zinc uptake by rhesus monkeys show similar kinetics to the rat, with a rapid first phase and slower second phase of accumulation (37). Due to the limited amount of tissue, the specific transport mechanism of hepatic zinc uptake and efflux was not further characterized in this study. The intracellular distribution of ${ }^{65} \mathrm{Zn}$ showed that it was associated with a very low mol wt ligand. Similar findings have been reported in primary rat hepatocyte cultures (38). In our study, the ${ }^{65} \mathrm{Zn}$ in the monkey hepatocyte supernatant eluted at a similar time as glutathione-bound ${ }^{65} \mathrm{Zn}$. The above findings indicate that the rat and rhesus monkey have considerable similarities in the kinetics of hepatic zinc metabolism.

Two additional observations that can be drawn from the liver mineral data concern the copper and manganese values. For both $\mathrm{C}$ and $\mathrm{M}$ infants, liver copper concentrations were almost 10 times higher than typical values reported for adults, whereas manganese concentrations were about half of adult values (18, 39 ). This observation is similar to what has been observed for several species including humans (40-44), and supports the idea that the neonate is born with considerable liver copper stores, 
whereas the transfer of manganese to the fetus and/or its retention is very low.

The activities of SOD enzymes were measured in the current study for two reasons. First, CuZnSOD has an absolute requirement for zinc, and second, it has been reported that increased tissue lipid peroxidation may be one consequence of zinc deficiency $(45,46)$. One mechanism by which increased tissue lipid peroxidation could occur is via a reduction in the activities of the antioxidant enzymes, CuZnSOD and/or MnSOD $(47,48)$. Although there was a correlation between zinc concentration and the activity of CuZnSOD activity $(r=0.50 ; p=0.01)$, the extent of the zinc deficiency was not severe enough in our study to result in a reduction in the activity of CuZnSOD. This lack of an effect of moderate dietary zinc deprivation on liver SOD activity in infants is similar to data obtained for adult rhesus monkeys (21).

In summary, these data show that when pregnant monkeys are fed a diet that is only marginally deficient in zinc, perturbations in the responsiveness of the mothers' immune system can occur even in the absence of overt signs of zinc deficiency. Similarly, infants born to dams fed the marginal zinc diets can be characterized by reduced immune responsiveness relative to control infants despite the absence of marked differences in plasma or soft tissue zinc concentrations in the two groups of infants.

\section{REFERENCES}

1. Keen CL, Hurley LS 1989 Zinc and reproduction: effects of deficiency on foetal and postnatal development. In: Mills CF (ed) Zinc in Human Biology. Springer-Verlag, London, pp 183-220

2. Agpar J1985 Zinc and reproduction. Ann Rev Nutr 5:43-68

3. Swanson CA, King JC 1987 Zinc and pregnancy outcome. Am J Clin Nutr 46:763-771

4. Golub MS, Gershwin ME, Hurley LS, Baly DL, Hendrickx AG 1984 Studies of marginal zinc deprivation in rhesus monkeys. I. Influence on pregnant dams. Am J Clin Nutr 39:265-280

5. Golub MS, Gershwin ME, Hurley LS, Baly DL, Hendrickx AG 1984 Studies of marginal zinc deprivation in rhesus monkeys. II. Pregnancy outcome. Am J Clin Nutr 39:879-887

6. Haynes DC, Gershwin ME, Golub MS, Cheung ATW, Hurley LS, Hendrickx AG 1985 Studies of marginal zinc deprivation in rhesus monkeys. VI. Influence on the immunohematology of infants in the first year. Am $J$ Clin Nutr 42:252-262

7. Golub MS, Gershwin ME, Hurley LS, Hendrickx AG, Saito WV 1985 Studies of marginal zinc deprivation in rhesus monkeys: Infant behavior. Am J Clin Nutr 42:1229-1239

8. Golub MS, Gershwin ME, Hurley LS, Saito WY, Hendrickx AG 1984 Studies of marginal zinc deprivation in rhesus monkeys. IV. Growth of infants in the first year. Am J Clin Nutr 40:1 192-1202

9. Leek JC, Keen CL, Vogler JB, Golub MS, Hurley LS, Hendrickx AG, Gershwin ME 1988 Long-term marginal zinc deprivation in rhesus monkeys. IV. Effects on skeletal growth and mineralization. Am J Clin Nutr 47:889895

10. Hambidge KM, Krebs NF, Sibley L, English J 1987 Acute effects of iron therapy on zinc status during pregnancy. Obstet Gynecol 70:593-596

11. Fairweather-Tait SJ, Payne V, Williams CM 1984 The effect of iron supplements on pregnancy in rats given a low-zinc diet. Br J Nutr 52:79-86

12. Sheldon WL, Aspillaga MO, Smith PA, Lind T 1985. The effects of oral iron supplementation on zinc and magnesium levels during pregnancy. $\mathrm{Br} \mathbf{J}$ Obstet Gynaecol 92:892-899

13. Bloxan DL, Williams NR, Waskett RJD, Pattinson-Green PM, Morarji Y, Stewart SG 1989 Maternal zinc during oral supplementation in pregnancy: a preliminary study. Clin Sci 76:59-65

14. Reinstein NH, Lönnerdal B, Keen CL, Hurley LS 1984 Zinc-copper interactions in the pregnant rat. Fetal outcome and maternal and fetal zinc, copper and iron. J Nutr 114:1266-1279

15. Darwish HM, Schmitt RC, Cheney JC, Ettinger MJ 1984 Copper efflux kinetics from rat hepatocytes. Am J Physiol 246:G48-G55

16. Clegg MS, Keen CL, Lönnerdal B, Hurley LS 1981 Influence of ashing techniques on the analysis of trace elements in animal tissues. I. Wet ashing. Biol Trace Element Res 3:107-115

17. Giroux EL 1975 Determination of zinc distribution between albumin and alpha-2-macroglobulin in human serum. Biochem Med 12:258-266

18. Onosaka S, Cherian MG 1982 Comparison of metallothionein determination by polarographic and cadmium-saturation methods. Toxicol Appl Pharmacol 63:270-274

19. Marklund S, Marklund G 1974 Involvement of the superoxide anion-radical in the autooxidation of pyrogallol and a convenient assay for superoxide dismutase. Eur J Biochem 41:469-474

20. Committee on Care and Use of Laboratory Animals, Institute of Laboratory Animal Resources, Commission on Life Sciences, National Research Council. 1985 National Institutes of Health, Bethesda, MD (NIH publication no. 2:85-22)

21. Keen CL, Golub MS, Gershwin ME, Lönnerdal B, Hurley LS 1988 Studies of marginal zinc deprivation in rhesus monkeys. III. Use of liver biopsy in the assessment of zinc status. Am J Clin Nutr 47:1041-1045

22. Solomons NW 1979 On the assessment of zinc and copper nutriture in man. Am J Clin Nutr 32:856-871

23. Sato M, Mehra RK, Bremner I 1984 Measurement of plasma metallothionein$\mathrm{I}$ in the assessment of zinc status of zinc-deficient and stressed rats. J Nutr 114:1683-1689

24. Duchaleau J, Delepesse G, Vrijens R, Collet H 1981 Beneficial effects of oral zinc supplementation on the immune response to mitogens of normal subjects. Am J Med 70:1001-1004

25. Allen JI, Kerchik W, Kay NE, McClain CJ 1982 Zinc and T-lymphocyte function in hemodialysis patients. Am J Clin Nutr 36:410-415

26. Mooradian AD, Norman DC, Morley JE 1988 The effect of zinc status on the immune function of diabetic rats. Diabetologia 31:703-707

27. Niewoehner CB, Allen JI, Boosalis M, Levine AS, Morley JE 1986 Role of zinc supplementation in Type 2 diabetes mellitus. Am J Med 81:63-68

28. Mukherjee MD, Sandstead HH, Ratnaparkhi MV, Johnson LK, Milne DB, Stelling HP 1984 Maternal zinc, iron, folic acid and protein nutriture and outcome of human pregnancy. Am J Clin Nutr 40:496-507

29. Haynes DC, Golub MS, Gershwin ME, Cheung ATW, Hurley LS, Hendrickx AG 1987 Long-term marginal zinc deprivation in rhesus monkeys. I. Effects on adult female breeders before conception. Am J Clin Nutr 45:1492-1502

30. Zlotkin SH, Cherian MG 1988 Hepatic metallothionein as a source of zinc and cysteine during the first year of life. Pediatr Res 24:326-329

31. Hamer DH 1986 Metallothionein. Ann Rev Biochem 55:913-951

32. McMichael AJ, Dreosti IE, Gibson GT, Hartshorne JM, Buckley PA, Colley DP 1982 A prospective study of serial maternal zinc levels and pregnancy outcome. Early Hum Dev 7:59-69

33. Prema K 1981 Predictive value of serum copper and zinc in normal and abnormal pregnancy. Indian J Med Res 71:534-560

34. Metcoff J, Costiloe JP, Crosby W, Bentle L, Seshachalam D, Sandstead HH Bodwell CE, Weaver F, McClain P 1981 Maternal nutrition and fetal outcome. Am J Clin Nutr 34:708-721

35. Lönnerdal B, Keen CL, Hendrickx AG, Golub MS, Gershwin ME 1989 The influence of dietary zinc and iron on zinc absorption/retention in pregnant rhesus monkeys and their infants. FASEB $\mathrm{J}$ 3:A456(abstr)

36. House WA, Welch RM, Van Campen D 1989 Zinc accumulation by hepatocytes isolated from male rats of different zinc nutritional status. In: Hurley LS, Keen CL, Lonnerdal B, Rucker RB (eds) Trace Elements in Man and Animals (TEMA-6). Plenum Press, New York, pp 421-422

37. Stacey NH, Klaasen CD 1981 Zinc uptake by isolated rat hepatocytes. Biochim Biophys Acta 640:693-697

38. Failla ML, Cousins RJ 1978 Zinc uptake by isolated rat liver parenchymal cells. Biochim Biophys Acta 538:435-444

39. Keen CL, Tamura T, Lönnerdal B, Hurley LS, Halsted CH 1985 Changes in hepatic superoxide dismutase activity in monkeys. Am J Clin Nutr 41:929932

40. Keen CL, Hurley LS 1980 Developmental changes in concentrations of iron copper, and zinc in mouse tissues. Mech Aging Develop 13:161-176

41. Bruckmann G, Zondek SG 1939 CCXXIX Iron, copper and manganese in human organs at various ages. Biochem J 33:1845-1857

42. Terao T, Owen CA 1977 Copper metabolism in pregnant and postpartum rat and pups. Am J Physiol 232:E172-E179

43. Davis GK, Mertz W 1987 Copper. In: Mertz W (ed) Trace Elements in Human and Animal Nutrition, 5th ed. Academic Press, San Diego, pp 301-364

44. Hurley LS, Keen CL 1987 Manganese. In: Mertz W (ed) Trace Elements in Human and Animal Nutrition, 5th ed. Academic Press, San Diego, pp 185 223

45. Willson RL 1989 Zinc and iron in free radical pathology and cellular control In: Mills CF (ed) Zinc in Human Biology. Springer-Verlag, London, pp 147172

46. Bray TM, Kubow S, Bettger WJ 1986 Effect of dietary zinc on endogenous free radical production in rat lung microsomes. J Nutr 1 16:1054-1060

47. Zidenberg-Cherr S, Keen CL, Lönnerdal B, Hurley LS 1983 Superoxide dismutase and lipid peroxidation: developmental correlations affected by Mn deficiency. J Nutr 1 13:2498-2504

48. Balevska PS, Russanov EM, Kassabova TA 1981 Studies on lipid peroxidation in rat liver by copper deficiency. Int J Biochem 13:489-493 